\title{
Cardosins: A New and Efficient Plant Enzymatic Tool to Dissociate Neuronal Cells for the Establishment of Cell Cultures
}

\author{
A.S. Duarte, ${ }^{1}$ N. Rosa, ${ }^{2}$ E.P. Duarte, ${ }^{3}$ E. Pires,${ }^{4}$ M.T. Barros ${ }^{2,5}$ \\ ${ }^{l}$ CESAM and Departamento de Biologia, Universidade de Aveiro, Aveiro, Portugal \\ ${ }^{2}$ Universidade Católica Portuguesa, Polo de Viseu, 3504-505 Viseu, Portugal \\ ${ }^{3}$ Departamento de Zoologia and Centro de Neurociências e Biologia Celular, \\ Universidade de Coimbra, Coimbra, Portugal \\ ${ }^{4}$ Departamento de Bioquímica and Centro de Neurociências e Biologia Celular, \\ Universidade de Coimbra, Coimbra, Portugal \\ ${ }^{5} \mathrm{CBC}$ and Departamento de Biologia, Universidade de Aveiro, 3810-193 Aveiro, Portugal; \\ telephone: +351-234370970; fax: +351-234426408; e-mail: mbarros@bio.au.pt \\ Received 4 April 2006; accepted 24 October 2006 \\ Published online 10 November 2006 in Wiley InterScience (www.interscience.wiley.com). DOI 10.1002/bit.21259
}

\begin{abstract}
In the present work, we examined the feasibility of using cardosins, plant aspartic-proteinases from Cynara cardunculus L., to isolate cells from rat embryonic brain. Using morphological and functional assays, we compared cell cultures obtained with cardosins with those prepared with a well-established trypsin protocol. Cardosins and trypsin dissociation produced cells with similar yield, viability, and GABA release in response to a depolarizing stimulus. However, cardosins-dissociated cells appeared to recover faster in culture, as assessed by the MTT-test and by the number and length of neurtites, suggesting that cardosins are less aggressive to neurons than trypsin. This feature might be helpful for research and medical purposes requiring fast manipulations of cells.

Biotechnol. Bioeng. 2007;97: 991-996.

(C) 2006 Wiley Periodicals, Inc.
\end{abstract}

KEYWORDS: cardosins; tissue dissociation; cell viability; neuronal cultures; trypsin

\section{Introduction}

The establishment of primary cell cultures is a widely used tool in Molecular Biology, Toxicology, and Biotechnology. Cell culture requires that the tissue be dispersed into a cell suspension, which is usually achieved by a combined mechanical and enzymatic procedure. Trypsin is by far the most common enzyme used in tissue disaggregation, since it

Correspondence to: M.T. Barros

Contract grant sponsor: Fundação para a Ciência e Tecnologia (FCT), Portugal

Contract grant number: SFRH/BD/2998/2000 is well tolerated by many cells and has been demonstrated to be effective for many tissues (Andersen, 2002; Agostinho and Oliveira, 2003; Brewer, 1997; Hung et al., 2005; Svenningsen et al., 2003). The purer the trypsin, the less toxic it becomes. On the other hand, the cruder the trypsin, the more effective it may be due to other proteases present in the mixture. Nevertheless, it is important to minimize the exposure of cells to active enzymes to preserve maximum viability.

We have been working with cardosins, plant aspartic proteinases (AP) extracted from pistils of Cynara cardunculus, L., which show caseinolytic and collagenolytic activity towards specific peptide bonds (Duarte et al., 2005; Egas et al., 2000; Frazão et al., 1999; Pereira et al., 2005; Sarmento et al., 2003, 2006; Veríssimo et al., 1996), contrasting to trypsin that exhibit a wide specificity (Czapinska and Otlewski, 1999). The collagenase-like specificity of the enzyme, combined with its stability and ease of preparation, raised the possibility of its use for the establishment of primary cell cultures. Additionally, a new biotechnology project concerning large-scale production of cardosins for commercialization is being developed in Biocant (www. biocant.pt).

In the present study, we have developed a new protocol for embryonic brain dissociation using cardosins followed by the culture of neuronal cells in same commercially available defined media and the same plating substrates. Furthermore, cardosins appear to be less aggressive to

\section{(OWIIEY}


neuronal cells when compared to trypsin, allowing a faster cell recovery, a feature that might be important for research or medical purposes requiring fast processing of cells.

\section{Materials and Methods}

\section{Purification of Cardosins}

Cardosins were purified according to Sarmento et al. (2004), by a method that allows the purification of high amounts of protein. Briefly, stigmas from fresh flowers were homogenized in a mortar and pestle in sodium citrate $100 \mathrm{mM}, \mathrm{pH}$ 3.5, and centrifuged. The supernatant was applied to a Hiload Superdex 75 semi prep (Amersham, GE Healthcare, Buckinghamshire, UK) equilibrated and eluted with $25 \mathrm{mM}$ Tris- $\mathrm{HCl} \mathrm{pH} 7.6$ at a flow rate of $3 \mathrm{~mL} / \mathrm{min}$. Purity of cardosins was assessed by SDS-polyacrylamide gel electrophoresis (SDS-PAGE) according to Laemmli (1970). Cardosins solutions were concentrated by lyophilization. Dried protein was stored at $-80^{\circ} \mathrm{C}$.

\section{Cell Isolation and Culture}

Primary cultures of brain cortical cells were prepared from Wistar rat embryos (E15-E16) as described by Agostinho and Oliveira (2003) with minor modifications. Animals were handled following the approved guidelines of National Ethical Requirements for Animal Research and the European Convention for the Protection of Vertebrate Animals Used for Experimental and Other Scientific Purposes. Briefly, pregnant females were sacrificed by cervical dislocation, the uterus removed under sterile conditions, and the embryos dissected on a 100-mm Petri dish with cold $\mathrm{Ca}^{2+}$ - and $\mathrm{Mg}^{2+}$-free Hank's Balanced Salt Solution (CMFHBSS), $\mathrm{pH}$ 7.4. The cortecis were carefully removed and placed in CMF-HBSS containing $0.3 \%$ of BSA in a 35-mm Petri dish for subsequent removal of the meninges. After slightly mincing, the cortecis were digested with trypsin $(0.1 \%)$ or cardosins (concentrations indicated in the figure legends) in CMF-HBSS containing 0.008\% DNAse I (Sigma-Aldrich Chemical Co., St. Louis, MO), for $10 \mathrm{~min}$ at $37^{\circ} \mathrm{C}$. The digestion was stopped by adding $10 \%$ fetal calf serum (FCS) and washing. The digested tissue was mechanically dissociated by gentle forcing through a $5 \mathrm{~mL}$ glass pipette. After centrifugation (140g, $5 \mathrm{~min}$ ), the cells were resuspended in Neurobasal Medium supplemented with 2\% B27 (GIBCO, Invitrogen, Carlsbad, CA), $0.5 \mathrm{mM}$ L-glutamine, $100 \mathrm{U} / \mathrm{mL}$ penicillin, and $100 \mu \mathrm{g} / \mathrm{mL}$ streptomycin. Cell viability was assessed by Tripan blue exclusion and counting on a hemocytometer. The cells were plated on poly-D-lysine $(0.1 \mathrm{mg} / \mathrm{mL})$ coated multi-well plates, at a density of $0.5 \times 10^{6}$ cells $/ \mathrm{cm}^{2}$, or $10-\mathrm{mm}$ glass coverslips at a density of $0.25 \times 10^{6}$ cells $/ \mathrm{cm}^{2}$. The cells were maintained at $37^{\circ} \mathrm{C}$ in a humidified $5 \% \mathrm{CO}_{2} / 95 \%$ air atmosphere.

\section{MTT Assay of Cell Viability}

The viability of cultured cells was quantitatively assessed by the MTT (3-(4,5-dimethylthiazal-2-yl)-2,5-diphenyltetrazolium bromide) reduction test. Living cells convert MTT to a dark blue, water-insoluble formazan product formed by the reduction of the tetrazolium ring of MTT by the mitochondrial succinate dehydrogenase. The cultures were incubated with $300 \mu \mathrm{L}$ of MTT solution $(0.5 \mathrm{mg} / \mathrm{mL}$ in Krebs buffer) at $37^{\circ} \mathrm{C}$ for $2 \mathrm{~h}$. After washing, the cultures were incubated with $0.08 \mathrm{~N} \mathrm{HCl}$ in isopropanol to dissolve the blue formazan product, and the optical density read at $570 \mathrm{~nm}$ in a microplate reader with background subtraction at $620 \mathrm{~nm}$. Results were expressed as percentage of the optical density in controls.

\section{Immunocytochemistry}

Cell identity and morphology were evaluated after the immunocytochemical labelling of the neurons with an antiMAP-2 (microtubule-associated protein 2) antibody, and the astrocytes with an anti-GFAP (glial fibrillary acidic protein) antibody (Sigma-Aldrich Chemical Co). After removing the culture medium and washing with phosphate buffered saline (PBS), the cells were fixed with $4 \%$ paraformaldehyde in PBS for $10 \mathrm{~min}$, followed by permeabilization with $0.2 \%$ Triton X-100 in PBS for 10 min. After blocking for 90 min with $0.2 \%$ gelatin in PBS, the cells were incubated with the anti-MAP-2 (1:500) and antiGFAP (1:200) antibodies for $90 \mathrm{~min}$. After extensive washes in PBS, the cells were incubated for $60 \mathrm{~min}$ with the secondary antibodies: anti-mouse IgG conjugated to Alexa Fluor $594(2 \mu \mathrm{g} / \mathrm{mL})$ and anti-rabbit IgG conjugated to Alexa Fluor $498(1 \mu \mathrm{g} / \mathrm{mL})$ (Molecular Probes, Invitrogen). To assess the specificity of the immunostaining, the primary antibodies were omitted in some coverslips. Finally, the coverslips were washed thoroughly and mounted on glass slides in fluorescent mounting medium (DAKO Corporation, Copenhagen, Denmark). The preparations were observed in a Carl Zeiss fluorescence microscope, and images were acquired with the AxioVision software (Carl Zeiss Imaging Systems, Maple Grove, MN). The number of neurites and their length were evaluated in four randomized areas, in three independent preparations, with the AxioVision software, and statistically evaluated with Student's $t$-test.

\section{GABA Release}

The release of GABA was determined after loading the cells with $\left[{ }^{3} \mathrm{H}\right]$ GABA (Amersham) as a tracer. After removing the culture medium and washing, the cells were incubated for $45 \mathrm{~min}$ at $37^{\circ} \mathrm{C}$, in $\mathrm{Na}^{+}$-medium (in mM: $132 \mathrm{NaCl}$, $4 \mathrm{KCl}, 1.4 \mathrm{MgCl}_{2}, 1.2 \mathrm{H}_{3} \mathrm{PO}_{4}, 1 \mathrm{CaCl}_{2}, 6$ glucose, $10 \mathrm{HEPES}-$ $\mathrm{Na}, \mathrm{pH}$ 7.4) containing $25 \mathrm{nM}$ GABA and $1 \mu \mathrm{Ci} / \mathrm{mL}$ $\left[{ }^{3} \mathrm{H}\right] \mathrm{GABA}$, in the presence of $10 \mu \mathrm{M}$ aminooxyacetic acid 
(AOAA, an inhibitor of the GABA transaminase) to prevent GABA degradation. After loading with the radioactive neurotransmitter, the cells were washed three times with $\mathrm{Na}^{+}$-medium, and further incubated for $15 \mathrm{~min}$ at $37^{\circ} \mathrm{C}$. In order to depolarize the cells and to stimulate neurotransmitter release, the medium was replaced by medium containing $50 \mathrm{mM} \mathrm{KCl}(\mathrm{NaCl}$ was partially substituted by $\mathrm{KCl}$ to maintain the isoosmolarity), supplemented with $10 \mathrm{mM}$ NNC-711 (1-(2-(((diphenylmethylene(amino)oxy)ethyl)-1,2,5,6-tetrahydro-pyridine-carboxylic acid hydrochloride))) to prevent GABA reuptake. At the end of each experiment, the cells were lysed in $0.2 \mathrm{M} \mathrm{HCl}$, for 5 min, to determine the remaining intracellular $\left[{ }^{3} \mathrm{H}\right]$ GABA. The radioactivity was measured using Universol scintillation cocktail (ICN) and a Packard 2000 Spectometer provided with dpm correction. GABA release was expressed as the percentage of the initial intracellular content $\left(\left[{ }^{3} \mathrm{H}\right] \mathrm{GABA}\right.$ left in cells plus $\left[{ }^{3} \mathrm{H}\right] \mathrm{GABA}$ released).

\section{Data Analysis}

Data are expressed as means \pm SEM. Statistical significance was determined by using Student's $t$-tests, ${ }^{*} P \leq 0.05$, ${ }^{* *} P \leq 0.001$, and ${ }^{* * *} P \leq 0.001$, for significant, very significant, and extremely significant, respectively, as indicated in the figure legends.

\section{Results and Discussion}

\section{Cell Yield and Viability}

To study the feasibility of using cardosin to prepare neuronal cell cultures, we determined its ability to dissociate cortical tissue from rat embryonic brain, and we compared the cell yield and the cell viability with those obtained with an established protocol to prepare cortical cultures using trypsin (Agostinho and Oliveira, 2003). Figure la shows the cell yield of cortex dissociation with increasing concentrations of our preparation of cardosins containing cardosins A and $\mathrm{B}$. Cortex dissociation with $1 \mathrm{mg} / \mathrm{mL}$ cardosins yielded a number of cells, approximately $20 \times 10^{6}$ cells/mg wet tissue, similar to the yield obtained with trypsin at the concentration routinely used in our laboratory to isolate cortical cells from rat embryos. The percentage of viable cells isolated with cardosins $(86.49 \% \pm 0.81$ of total $)$ was quite similar to the viability of cells dissociated with trypsin $(85.56 \% \pm 3.30)$. Significantly, the viability of cells obtained with cardosins was less variable (Fig. 1b) than those obtained with trypsin. Heretofore, the concentration of cardosins used for the isolation of cortical cells was $1 \mathrm{mg} / \mathrm{mL}$ since the cell yield was similar to that obtained with trypsin, and the use of higher concentrations of cardosins did not further increase the cell yield.

Cell viability was also examined upon culturing the cells (Fig. 2). Using the MTT reduction assay, we observed similar viabilities of cells isolated with cardosins or trypsin $3 \mathrm{~h}$ after plating, but at $24 \mathrm{~h}$, the viability of cells that have been isolated with cardosins was much higher than the viability of cells isolated with trypsin $(P \leq 0.001)$. The difference in viability was no longer significant upon 7 days in culture. The increase in cell viability observed upon culturing is due to cell recovery after the isolation and to the death and detachment of nonviable cells, leading to the increase in the percentage of cells capable of reducing MTT. The faster increase in cell viability observed for the cells isolated with cardosins as compared to cells isolated with trypsin suggests that cardosins are less harmful to neuronal cells.
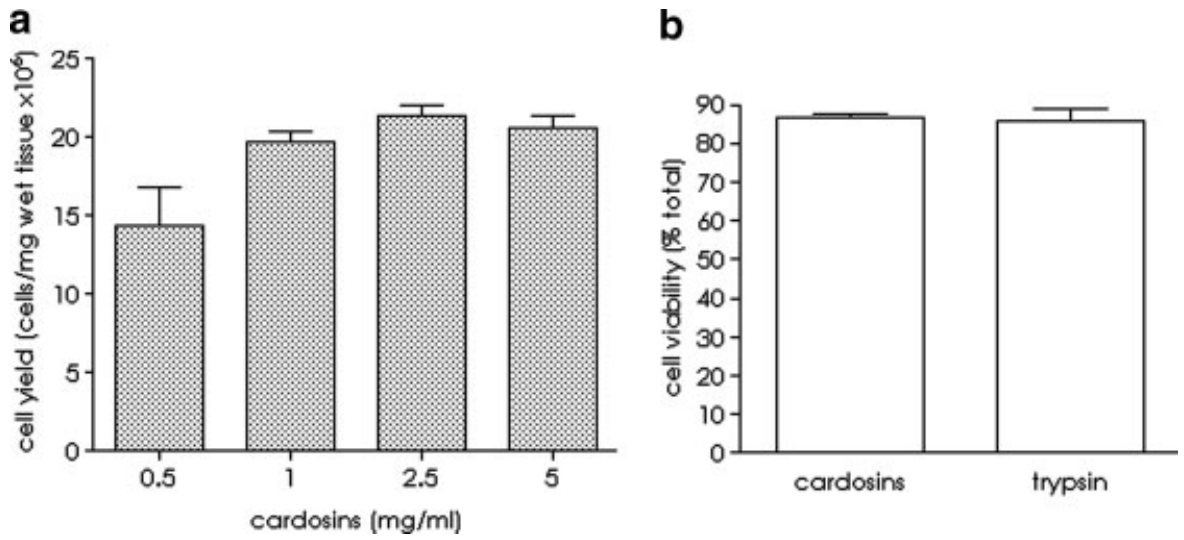

Figure 1. Cell yield of brain cortex dissociation with cardosins or trypsin. a: Concentration dependence of cell dissociation with cardosins. Cortices from 15 or 16 days-old rat embryos were weighed, minced, and incubated at $37^{\circ} \mathrm{C}$ with the indicated concentrations of cardosins. At the end of the isolation procedure, the cells were counted in a hemocytometer. The results are the means \pm SEM of at least three preparations. $\mathbf{b}$ : Comparison of the viability of freshly isolated cells with cardosins ( $1 \mathrm{mg} / \mathrm{mL}$ ) or trypsin (1 $\mathrm{mg} / \mathrm{mL})$. At the end of the isolation procedure, the cells were diluted in $\mathrm{Na}^{+}$medium containing Trypan blue, and observed in the hemocytometer. Cell viability was expressed as the percentage of cells that excluded the dye. The results are the means \pm SEM of eight independent preparations performed in parallel with cardosins and trypsin. 


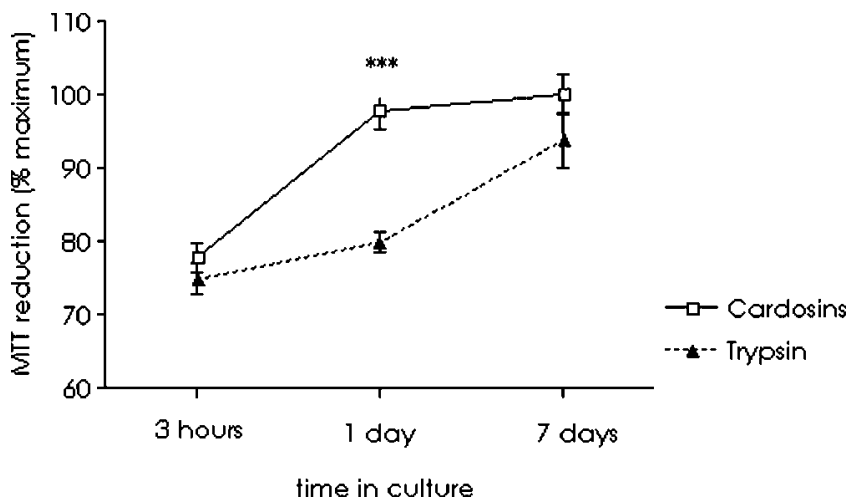

Figure 2. Viability of cell cultures prepared by tissue dissociation with cardosins $(\square) \operatorname{or} \operatorname{trypsin}(\boldsymbol{\Lambda})$, both at $1 \mathrm{mg} / \mathrm{mL}$. Cell viability was assessed with the MTT reduction assay upon $3 \mathrm{~h}, 24 \mathrm{~h}$, and 7 days in culture. Data were expressed as percentage of the maximal reduction observed for cells isolated with cardosins upon 7 days in culture. The results are the means \pm SEM of at least three determinations performed in triplicate in independent preparations.

\section{Immunocytochemical and Morphometric Analysis of Cell Cultures}

In order to identify the cells present in the cultures and to follow their development, we immunolabeled the cultures for a neuron-specific protein, MAP-2, and for a glial cell marker, GFAP. The immunofluorescence images (Fig. 3) show that neurons, isolated with cardosins and subsequently cultured, exhibited a normal morphology, with neurites extending from the cell bodies, demonstrating a normal cellular growth, as a result of re-expression of neuritogenesis, apparently without damage. Actually, longer neurites were observed in cultures prepared with cardosins, $24 \mathrm{~h}$ after plating, as compared to the cultures of cells dissociated with trypsin (Fig. 3a and b), but the differences were no longer apparent in cells cultured for longer periods (Fig. 3c and e). Quantitative analysis showed that neurons isolated with cardosins exhibited more and longer neurites (Fig. 4). The number of neurites extending longer than $25 \mu \mathrm{m}$ was $68.0 \pm 5.0$ in cells that had been isolated using cardosins,
Cardosins
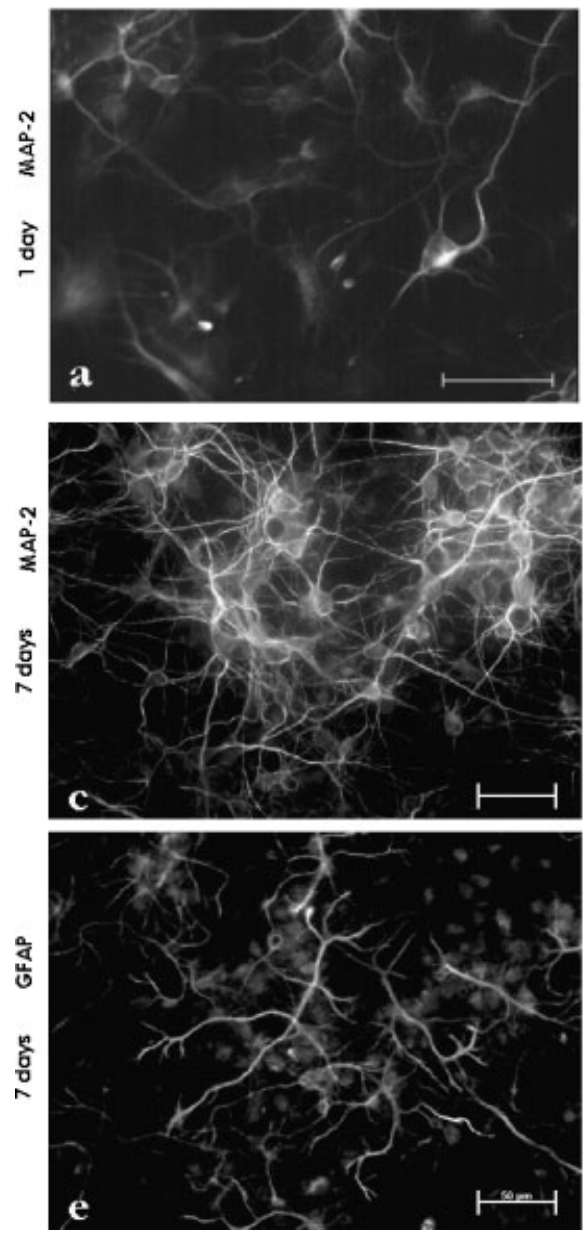

Trypsin
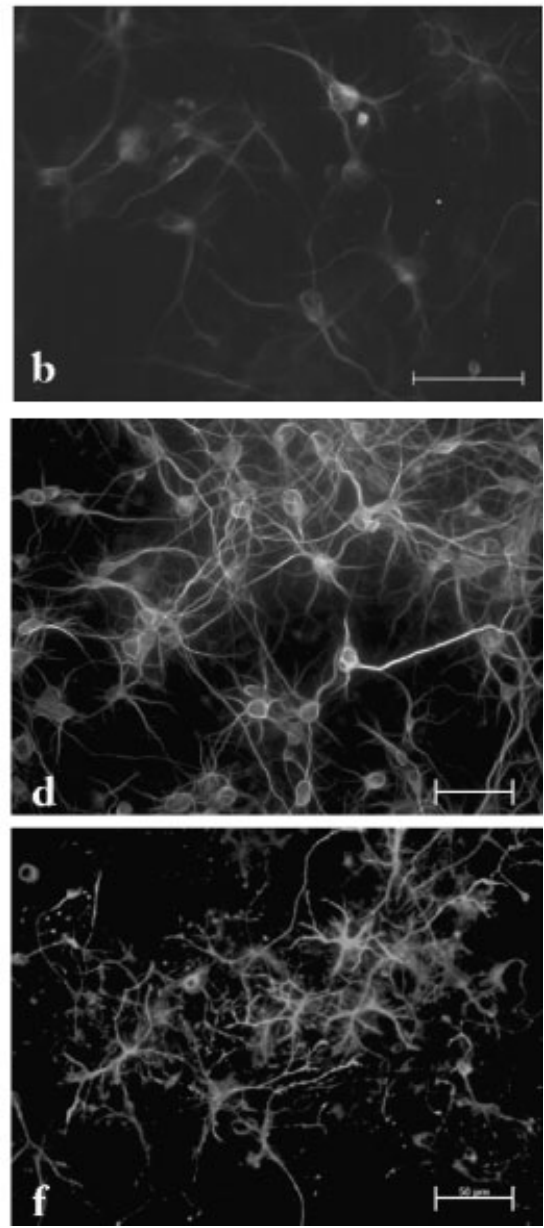

Figure 3. Immunocytochemical characterization of cell cultures prepared by cardosins or trypsin dissociation of embryonic brain cortex. The cells were cultured for 1 day (a, b), or for 7 days (c-f) before fixation and immunolabeling for MAP-2 (a-d), a neuronal marker, and for GFAP (e, f), a glial marker. Fluorescence microphotographies (c) and (e), and (d) and (f) are from the same fields. (Scale bar $=50 \mu \mathrm{m})$. 


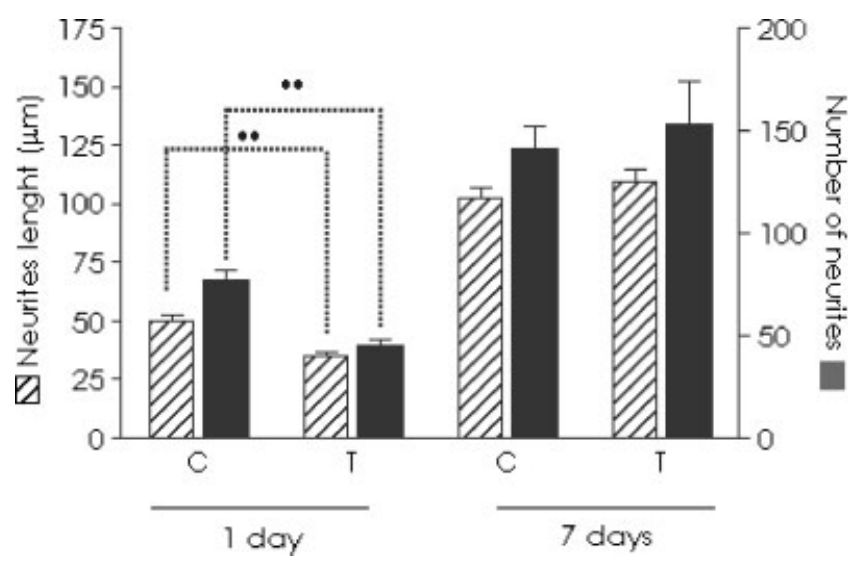

Figure 4. Morphometric analysis of neurons cultured for 1 or 7 days after cell isolation with cardosins $(\mathrm{C})$ or trypsin $(\mathrm{T})$. The cultures were immunostained for MAP2 , and the neurite length and the number of neurites extending longer then $25 \mu \mathrm{m}$ were determined in four randomly chosen fields. Data shown are the means \pm SEM of determinations in three independent preparations.

which is significantly larger than in trypsin isolated cells $(39.5 \pm 4.0, P \leq 0.01)$. Their maximal length was $35.0 \pm$ $4.0 \mu \mathrm{m}$ in trypsin-generated cultures, and $50 \pm 6.0 \mu \mathrm{m}$ $(P \leq 0.01)$ in cultures obtained with cardosins. No differences were perceptible after 7 days in culture. These morphological data are in agreement with cell viability data shown in Figure 2.

Immunostaining for GFAP was not observed at 1 day in culture (data not shown). Therefore, the differences in the neuronal development cannot be accounted for by differences in astrocyte support. Moreover, 7 days-old cultures showed a similar and marked astrocytic development, both in cardosin and trypsin cultures. The astrocyte growth was not unexpected since the Neurobasal medium with the B27 supplement does not hinder the proliferation of nonneuronal cells.

\section{Functional Analysis of Cell Cultures}

To examine whether the cell cultures prepared with cardosins exhibit physiological responses, we performed an assay of neurotransmitter release in response to membrane depolarization (Fig. 5). The neurotransmitter GABA was chosen because of its abundance in the cortex and because its release from cultured cells is well characterized (Santos et al., 1998). GABA release in the absence of stimulation was quite high, about $15 \%$ of the total cell content, but similar in cardosin- and trypsinprepared cultures. This elevated release of neurotransmitters in the absence of stimulation is often observed in embryonic cultures due to high levels of spontaneous activity (van den Pol et al., 1998). Upon depolarization induced by increasing $\mathrm{K}^{+}$concentration in the extracellular medium, we observed an additional release of GABA, about $5 \%$ of the cell content,

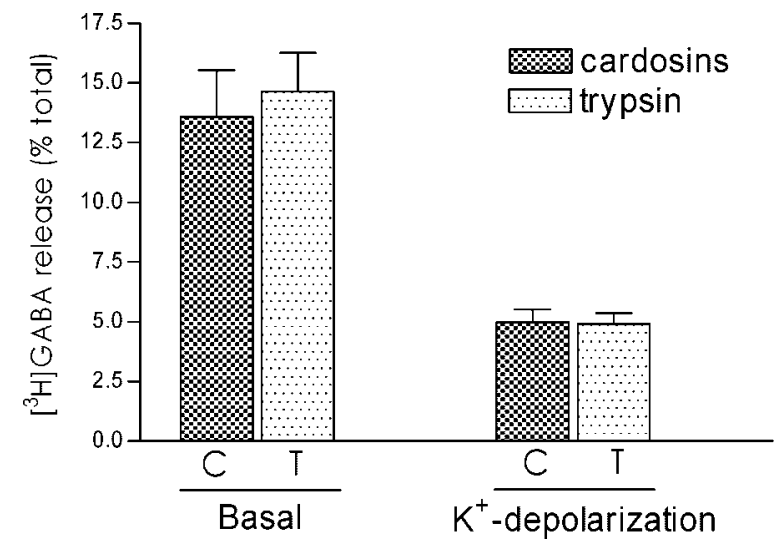

Figure 5. Comparison of GABA release from cultures prepared with cardosins or trypsin. After cell loading with $\left.{ }^{3} \mathrm{H}\right] \mathrm{GABA}, \mathrm{GABA}$ release was determined in $\mathrm{Na}^{+}$ medium (Basal) or in medium containing $50 \mathrm{mM} \mathrm{K}^{+}$(prepared from $\mathrm{Na}^{+}$medium by replacing isosmotically $\mathrm{NaCl}$ by $\mathrm{KCl}$ ). $\mathrm{GABA}$ release evoked by $\mathrm{K}^{+}$depolarization was calculated by subtracting release in $\mathrm{Na}^{+}$medium from the release in medium containing $50 \mathrm{mM} \mathrm{K}^{+}$. Values are expressed as the percentage of total cell content. Data shown are the means \pm SEM of three independent determinations performed in triplicate.

showing that the cells were capable of responding to a depolarizing stimulus, as expected from cells keeping a membrane potential.

In summary, we show that cardosins, aspartic proteases of plant origin, can be used to dissociate neuronal tissue to prepare cell cultures. Cell yield and viability, and the composition in neuronal and glial cells were comparable to those obtained with trypsin digestion, but the improved cell viability at early stages of culture suggest that cardosins are less aggressive than trypsin. This feature is, most likely, associated to the more restrict specificity of cardosins, demonstrated for their collagenenase-like activity (Duarte et al., 2005).

This report raises the possibility of the application of cardosins for the isolation of other types of cells, taking advantage of their collagenolytic activity, which could be especially useful for tissues with a high content of collagen. Trypsin has been shown to be less efficient in these situations and collagenases are more expensive since they require a multi-step purification method (Dioszegi et al., 1995). In contrast, the cardosins mix is obtained by a single-step purification method yielding, approximately, $10 \mathrm{mg}$ of enzyme (Sarmento et al., 2004), which corresponds to five isolation procedures. Therefore, these APs, by themselves or in combination with other enzymes, constitute a promising tool, opening new avenues for cell isolation in tissues when other enzymes are not efficient. Finally, we propose that cardosins can be an alternative enzyme for subcultivation procedures, on the establishment of finite cultures and continuous cell lines, since it has been demonstrated at this point that the use of cardosins induces less cellular damage. This might prove useful for research and medical purposes whenever fast manipulation of cells is required. 
We are grateful to Dr. Paula Agostinho for helpful advice on the preparation of the cortical cell cultures, and to Dr. Paulo Santos for his assistance in the planning of the GABA release experiments. This work was supported by a $\mathrm{PhD}$ fellowship from Fundação para a Ciência e Tecnologia (FCT), Portugal—SFRH/BD/2998/2000.

\section{References}

Agostinho P, Oliveira CR. 2003. Involvement of calcineurin in the neurotoxic effects induced y beta-amyloid and prion peptides. Eur J Neurosci 17:1189-1196.

Andersen SS. 2002. Preparation of dissociated Zebrafish spinal neuron cultures. Methods Cell Sci 23:205-209.

Brewer GJ. 1997. Isolation and culture of adult rat hippocampal neurons. J Neurosci Meth 1:143-155.

Czapinska H, Otlewski J. 1999. Structural and energetic determinants of the S1-site specificity n serine proteases. Eur J Biochem 260:571-595.

Dioszegi M, Cannon P, Wart H. 1995. Vertebrate collagenases. Methods Enzymol 248:413-449.

Duarte AS, Pereira AO, Cabrita AS, Moir AJG, Pires E, Barros MT. 2005. The characterisation of the collagenolytic activity of cardosin A demonstrates its potential application for extracellular matrix degradative processes. Curr Drug Disc Technol 2:37-44.

Egas C, Lavoura N, Resende R, Brito RMM, Pires E, de Lima M, Faro C. 2000. The saposinlike domain of the plant aspartic proteinase precursor is a potent inducer of vesicle leakage. J Biol Chem 275:3819038196.

Frazão C, Bento I, Costa J, Soares CM, Veríssimo P, Faro C, Pires E, Cooper J, Carrondo MA. 1999. Crystal structure of cardosin A, a glycosylated and Arg-Gly-Asp-containing aspartic proteinase from the flowers of Cynara cardunculus L. J Biol Chem 274:27694-27701.
Hung PJ, Lee PJ, Sabounchi P, Lin R, Lee LP. 2005. Continuous perfusion microfluidic cell culture array for high-throughput cell-based assays. Biotechnol Bioeng 891: 1-8.

Laemmli UK. 1970. Cleavage of structural proteins during the assembly of the head of bacteriophage T4. Nature 227:680-685.

Pereira AO, Cartucho D, Duarte AS, Gil MH, Cabrita AMS, Patrício JA, Barros MMT. 2005. Immobilisation of cardosin A in chitosan sponges as a novel implant for drug delivery. Curr Drug Disc Technol 24: 231238.

Santos PF, Carvalho AL, Carvalho AP, Duarte CB. 1998. Differential acetylcholine and GABA release from cultured chick retina cells. Eur J Neurosci 10:2723-2730.

Sarmento AC, Oliveira CS, Pires E, Halling P, Barros M. 2003. Cardosin A as a model aspartic proteinase for the study of organic solvent effects. I. An overview on catalytic and structural aspects. J Mol Catal B: Enzym 21:19-23.

Sarmento AC, Oliveira CS, Pires EM, Amado F, Barros M. 2004. Reverse hydrolysis by cardosin A. Specificity considerations. J Mol Catal B: Enzym 28:33-37.

Sarmento AC, Oliveira CS, Duarte AS, Pires E, Barros MT. 2006. Evaluation of cardosin $\mathrm{A}$ as a probe for limited proteolysis in non-aqueous environments-Complex substrates hydrolysis. Enzyme Microb Tech 383-4: 415-421.

Svenningsen AF, Shan WS, Colman DR, Pedraza L. 2003. Rapid method for culturing embryonic neuron-glial cell cocultures. J Neurosci Res 72: 565-573.

van den Pol AN, Gao X-B, Patrylo PR, Ghosh PK, Obrietan K. 1998. Glutamate inhibits GABA excitatory activity in developing neurons. J Neurosci 18:10749-10761.

Veríssimo P, Faro C, Moir AJ, Lin Y, Tang J, Pires E. 1996. Purification, characterization and partial amino acid sequencing of two new aspartic proteinases from fresh flowers of Cynara cardunculus L. Eur J Biochem 235:762-768. 